\title{
Natural and anthropogenic atmospheric mercury in the European Arctic: a fractionation study
}

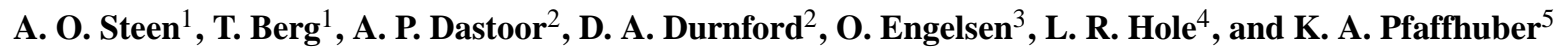 \\ ${ }^{1}$ Norwegian University of Science and Technology, Høgskoleringen 5, 7491 Trondheim, Norway \\ ${ }^{2}$ Air Quality Research Division, Science and Technology Branch, Environment Canada, 2121 Trans Canada Highway, \\ Dorval, Quebec, H9P 1J3, Canada \\ ${ }^{3}$ Norwegian Institute for Air Research, The Fram Centre, 9296 Troms $\varnothing$, Norway \\ ${ }^{4}$ Norwegian Meteorological Institute, Allegt. 70, 5007 Bergen, Norway \\ ${ }^{5}$ Norwegian Institute for Air Research, P.O. Box 100, 2027 Kjeller, Norway
}

Received: 15 September 2010 - Published in Atmos. Chem. Phys. Discuss.: 10 November 2010

Revised: 7 June 2011 - Accepted: 21 June 2011 - Published: 1 July 2011

\begin{abstract}
Gaseous elemental mercury (GEM) is converted to reactive gaseous mercury (RGM) during springtime Atmospheric Mercury Depletion Events (AMDE).

This study reports the longest time series of GEM, RGM and particle-bound mercury $(\mathrm{PHg})$ concentrations from a European Arctic site. From 27 April 2007 until 31 December 2008 composite GEM, RGM and PHg measurements were conducted in $\mathrm{Ny}-\mathrm{A} l$ esund $\left(78^{\circ} 54^{\prime} \mathrm{N}, 11^{\circ} 53^{\prime} \mathrm{E}\right)$. The average concentrations of the complete dataset were $1.6 \pm 0.3 \mathrm{ng} \mathrm{m}^{-3}, \quad 8 \pm 13 \mathrm{pg} \mathrm{m}^{-3}$ and $8 \pm 25 \mathrm{pg} \mathrm{m}^{-3}$ for GEM, RGM and PHg, respectively. For the complete dataset the atmospheric mercury distribution was $99 \%$ GEM, whereas RGM and PHg constituted $<1 \%$. The study revealed a seasonal distribution of GEM, RGM and PHg previously undiscovered in the Arctic. Increased concentrations of RGM were observed during the insolation period from March through August, while increased PHg concentrations occurred almost exclusively during the spring AMDE period in March and April. The elevated RGM concentrations suggest that atmospheric RGM deposition also occurs during the polar summer. RGM was suggested as the precursor for the $\mathrm{PHg}$ existence, but long range transportation of $\mathrm{PHg}$ has to be taken into consideration. Still there remain gaps in the knowledge of how RGM and PHg are related in the environment. RGM and PHg accounted for on average about $10 \%$
\end{abstract}

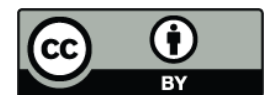

Correspondence to: A. O. Steen (anne.steen@chem.ntnu.no) of the depleted GEM during AMDEs. Although speculative, the fairly low RGM and PHg concentrations supported by the predominance of $\mathrm{PHg}$ with respect to RGM and no clear meteorological regime associated with these AMDEs would all suggest the events to be of non-local origin. With some exceptions, no clear meteorological regime was associated with the GEM, RGM and PHg concentrations throughout the year.

\section{Introduction}

Since the discovery of the Atmospheric Mercury Depletion Event (AMDE) in 1995, significant efforts have been carried out to understand this circumpolar phenomenon (Ariya et al., 2004; Schroeder et al., 1998; Skov et al., 2004). Gaseous elemental mercury (GEM) is converted to reactive gaseous mercury (RGM) during an AMDE. RGM denotes water soluble, divalent mercury and constitutes a minor part of the total atmospheric mercury (Lindberg and Stratton, 1998). RGM is subsequently either deposited or associated with aerosols (PHg) (Steffen et al., 2008).

The photochemically initiated heterogeneous production of halogen atoms $(\mathrm{Br}$ and $\mathrm{Cl})$ and halogen oxide radicals $(\mathrm{BrO}$ and $\mathrm{ClO})$ are assumed to be involved in the $\mathrm{Hg}$ oxidative mechanism (Goodsite et al., 2004). The reaction rate is possibly too slow for the oxidation of GEM by ozone to be prevalent (Peterson et al., 2009). A summary of the relative

Published by Copernicus Publications on behalf of the European Geosciences Union. 
importance of the halogen and ozone reactions is given in Holmes et al. (2009) where oxidation of GEM by $\mathrm{Br}$ accounts for $35-60 \%$ of the RGM, while oxidation by ozone and $\mathrm{Cl}$ contribute 5-20\% and 3-7\%, respectively. The reactive halogens are assumed to be generated from refreezing sea ice forming on open waters and UV radiation (Steffen et al., 2008). A summary of possible mechanisms for the release of reactive halogens from sea salt particles is given in George and Anastasio (2007). Halogen formation may also depend on nitric acid being the precursor for $\mathrm{OH}$ (Abbatt et al., 2010).

Mercury is emitted to the atmosphere by both natural and anthropogenic processes. Previously deposited atmospheric mercury, whether from natural or anthropogenic sources, may also be reemitted from both land and oceanic surfaces (Schroeder and Munthe, 1998). These Hg sources are all considered local, but have the capacity to contribute to the global Hg pool (Lindberg et al., 2007). With a lifetime of GEM on the order of $1 \mathrm{yr}, \mathrm{Hg}$ is found at remote Polar sites, far from its emission sources. RGM and PHg have atmospheric residence time on the order of days which restricting advection by winds (Schroeder and Munthe, 1998).

Studies reporting composite GEM, RGM and PHg measurements from Polar sites are conducted mainly in spring and restricted to the studies at Barrow $\left(71^{\circ} 19^{\prime} \mathrm{N}, 156^{\circ} 37^{\prime} \mathrm{E}\right)$, March-June 2001 (Lindberg et al., 2002), Alert (82 $58^{\prime} \mathrm{N}$, $62^{\circ} 38^{\prime} \mathrm{E}$ ), spring 2002 (Steffen et al., 2003b), Ny-Ålesund $\left(78^{\circ} 54^{\prime} \mathrm{N}, 11^{\circ} 53^{\prime} \mathrm{E}\right)$, April-May 2000 (Berg et al., 2003b), Ny-Ålesund, May 2002 (Berg et al., 2003a), Ny-Ålesund, April-May 2003 (Aspmo et al., 2005; Gauchard et al., 2005; Sprovieri et al., 2005) and Alert, January-July 2005 (Cobbett et al., 2007). Aspmo et al. (2006) and Sommar et al. (2010) reported GEM, RGM and PHg concentrations over the North Atlantic Ocean, however the RGM and PHg concentrations remained low during summer.

Although recent work suggests that several factors may control the relationship between RGM and PHg (for details see Sects. 3.1 and 3.2), the relative distribution of RGM and $\mathrm{PHg}$ is thought to indicate the age of an air parcel, and consequently the origin of an AMDE (Aspmo et al., 2005; Gauchard et al., 2005; Lindberg et al., 2002; Sprovieri et al., 2005, Steffen et al., 2003a). At Alert the predominant specie is $\mathrm{PHg}$, whereas RGM dominates at Barrow (Cobbett et al., 2007; Kirk, 2006; Lindberg et al., 2002; Steffen et al., 2005, 2003c). Gauchard et al. (2005) and Sprovieri et al. (2005) indicated no predominance of either RGM or PHg in NyÅlesund. Berg et al. (2003b) and Sommar et al. (2007) reported equal or larger PHg concentrations compared to RGM in Ny-Ålesund, suggesting AMDEs of non-local origin and deposition of mercury to snow and ice surfaces mainly outside the measurement site.

The present study discusses the longest time series of atmospheric GEM, RGM and PHg available from the European Arctic. We investigate the behaviour of the mercury fractions and discuss the main variables associated with the
GEM, RGM and PHg concentrations throughout the study period. Natural and anthropogenic emissions of GEM, RGM and PHg predicted by the Environment Canada's Global/ Regional Atmospheric Heavy Metal model (GRAHM) were used to better understand the observations in the this study.

\section{Experimental}

\subsection{Study site}

Composite RGM and PHg determinations were performed at the Zeppelin air monitoring station (henceforth named Zeppelin) from 27 April 2007 until 31 December 2008. Zeppelin is located $2 \mathrm{~km}$ from the settlement in Ny-Ålesund at an elevation of $474 \mathrm{~m}$ a.s.l. Ny-Ålesund is a research settlement located next to Kongsfjorden on the west coast of Spitsbergen (Fig. 1). The settlement is surrounded by steep mountains ranging in altitude from 500 to $1000 \mathrm{~m}$ to the south and east of Kongsfjorden and open sea to the north-west.

GEM has been sampled continuously at Zeppelin by the Norwegian Institute for Air Research (NILU) since 2000.

\subsection{Composite GEM, RGM and PHg measurements}

A Tekran 1130 denuder module and a Tekran 1135 particulate module were attached to the front end of a Tekran 2537A analyzer (cold vapor atomic fluorescence spectrometry, CVAFS) and provided semi-continuous concentrations of RGM and PHg. The Tekran 1130, 1135 and 2537A are henceforth named the fractionation system. The fractionation system was programmed to collect one-hour composite RGM and $\mathrm{PHg}$, while the preconcentrated RGM and PHg were determined in the following hour (Tekran method 35-2L5). A detailed description of this fractionation system is given in Landis et al. (2002) and Cobbett et al. (2007). A second Tekran 2537A was used to determine GEM at a five-minute resolution (for details see Sect. 3.2). The system is described elsewhere (Aspmo et al., 2005; Ebinghaus et al., 1999; Landis et al., 2002). Further details concerning the instrument at Zeppelin is given in Berg et al. (2003b).

The sample inlet for RGM and PHg measurements was located to the east, one $\mathrm{m}$ from the building wall and two $\mathrm{m}$ from the sample inlet for the determination of GEM.

GEM, RGM and PHg concentrations were reported in $\mathrm{ng} \mathrm{m}^{-3}$ and $\mathrm{pg} \mathrm{m}^{-3}$, respectively. The final concentrations of RGM and PHg were calculated as the sum of the heating cycles.

An AMDE is operationally defined in this paper as periods where the concentration of GEM $<1 \mathrm{ng} \mathrm{m}^{-3}$. Observation times are in Coordinated Universal Time (UTC).

\subsection{Ancillary data}

Back trajectory data derived by NILU used meteorological data which originated from the European Centre for Medium 

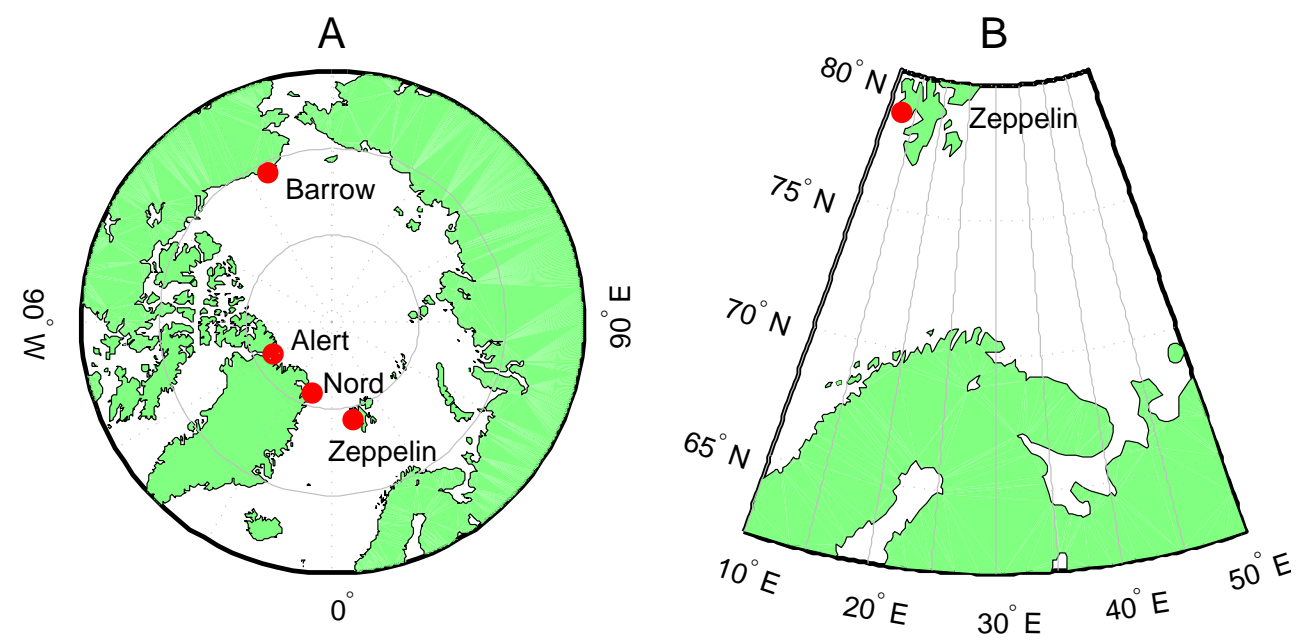

Fig. 1. (A) Map indicating the location of Polar study sites for atmospheric GEM, RGM and PHg measurements. (B) Map indicating the location of Zeppelin in Ny-Ålesund, on the Vest coast of Spitsbergen.

Range Weather Forecasts (ECMWF). The trajectories describe the potential source areas within the transport time to Ny-Ålesund. Since Zeppelin is located at $474 \mathrm{~m}$ a.s.l. air parcels arriving at $500 \mathrm{~m}$ height were used.

Monthly average $\mathrm{BrO}$ vertical densities were retrieved from the Scanning Imaging Absorption Spectrometer for Atmospheric Cartography (SCIAMACHY) instrument on board the satellite ENVISAT (Richter et al., 1998), and facilitated for tracking of the development and transport of $\mathrm{BrO}$ plumes in the Arctic boundary layer. It is important to note that parts of these $\mathrm{BrO}$ plumes are of stratospheric origin. Ozone data have therefore been used to verify the possibility of a so-called bromine explosion, since "BrO hotspots" have long been associated with the surface release of bromine and ozone depletion events (Salawitch et al., 2010).

Wind direction, air temperature, relative humidity and ozone reported from Zeppelin were provided by NILU. These ozone concentrations were recorded by UV absorption spectrometry (API 400A).

Measurements of UV erythemal hourly doserates (Dahlback, 1996) were obtained from the ground-based Ultraviolet Radiometer (GUV, Biospherical Instruments Inc.) on top of the Sverdrup Station in the Ny-Ålesund settlement at $25 \mathrm{~m}$ a.s.l. Applying the libRadtran simulation package (Mayer and Kylling, 2005), the erythemal UV measurements were transformed to UV quantities which are more related to the $\mathrm{Hg}$ measurements at Zeppelin, i.e. UVB hourly doserates at $474 \mathrm{~m}$ a.s.l. Being just about two $\mathrm{km}$ apart, the ambient cloud and surface conditions were assumed to be identical for both sites. However, the attenuation of air between $25 \mathrm{~m}$ a.s.l. and $474 \mathrm{~m}$ a.s.l. were corrected for, and the erythemally-effective UV doserates were converted to UVB doserates. All UV data from when the sun was below the horizon were ignored.

\subsection{Quality control}

Both Tekran 2537A instruments were auto-calibrated every $25 \mathrm{~h}$ using the instruments internal permeation source. Additionally, the accuracy of the GEM measurements was assured by manual injection of a known amount of GEM six times during the current study (Tekran 2505 instrument, mercury vapor primary calibration unit). The permeation rate was changed when the measured GEM was larger than $\pm 5 \%$ of the expected concentration.

The measurement error of the Tekran 2537A instrument is estimated to be $\pm 2 \%$ resulting in an average instrumental detection limit of $0.06 \mathrm{ng} \mathrm{m}^{-3}$ (Poissant et al., 2005). The sample inlet for GEM measurements was located $3 \mathrm{~m}$ above the surface snow, $2 \mathrm{~m}$ to the east of the station building. Further details are given in Berg et al. (2003b). Currently, no standardized calibration method exists to determine RGM and $\mathrm{PHg}$ concentrations. Since elevated concentrations of RGM and PHg were observed during non-AMDEs (Fig. 2), the method detection limit (MDL) was calculated as three times the standard deviation of the two last zero air measurements in a fractionation cycle. An MDL of $7 \mathrm{pg} \mathrm{m}^{-3}$ was calculated for the RGM and PHg measurements. The denuder and regenerable particulate filter (RPF) were replaced once a month. The denuders were blanked in situ. The soda lime was replaced every week. RGM and PHg concentrations were automatically corrected for flow rate and blank (i.e. mean of the two last zero air concentrations prior to the desorption).

Only Teflon lines and fittings were used. GEM, RGM and $\mathrm{PHg}$ concentrations less than the MDL were set to MDL/2 unless specified otherwise. 


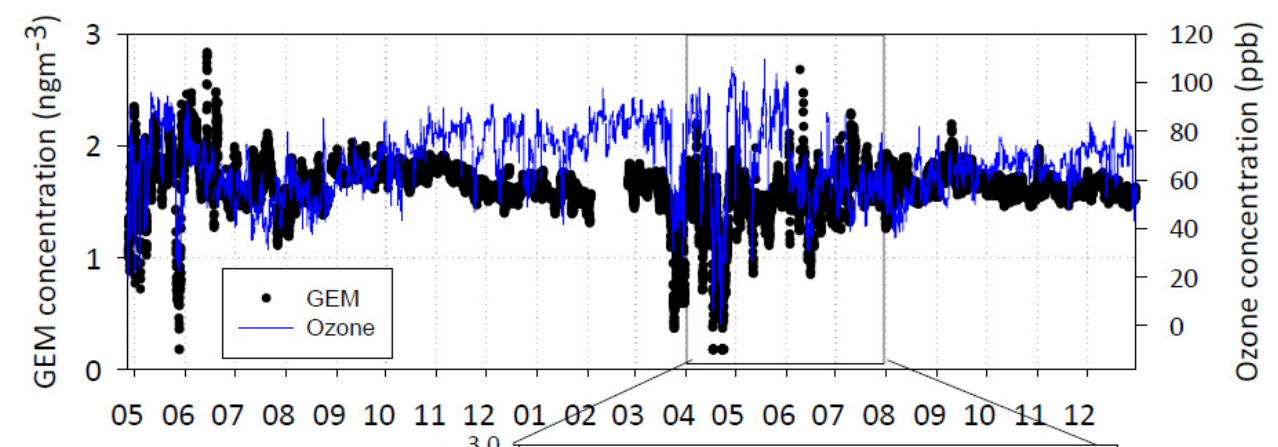

Month
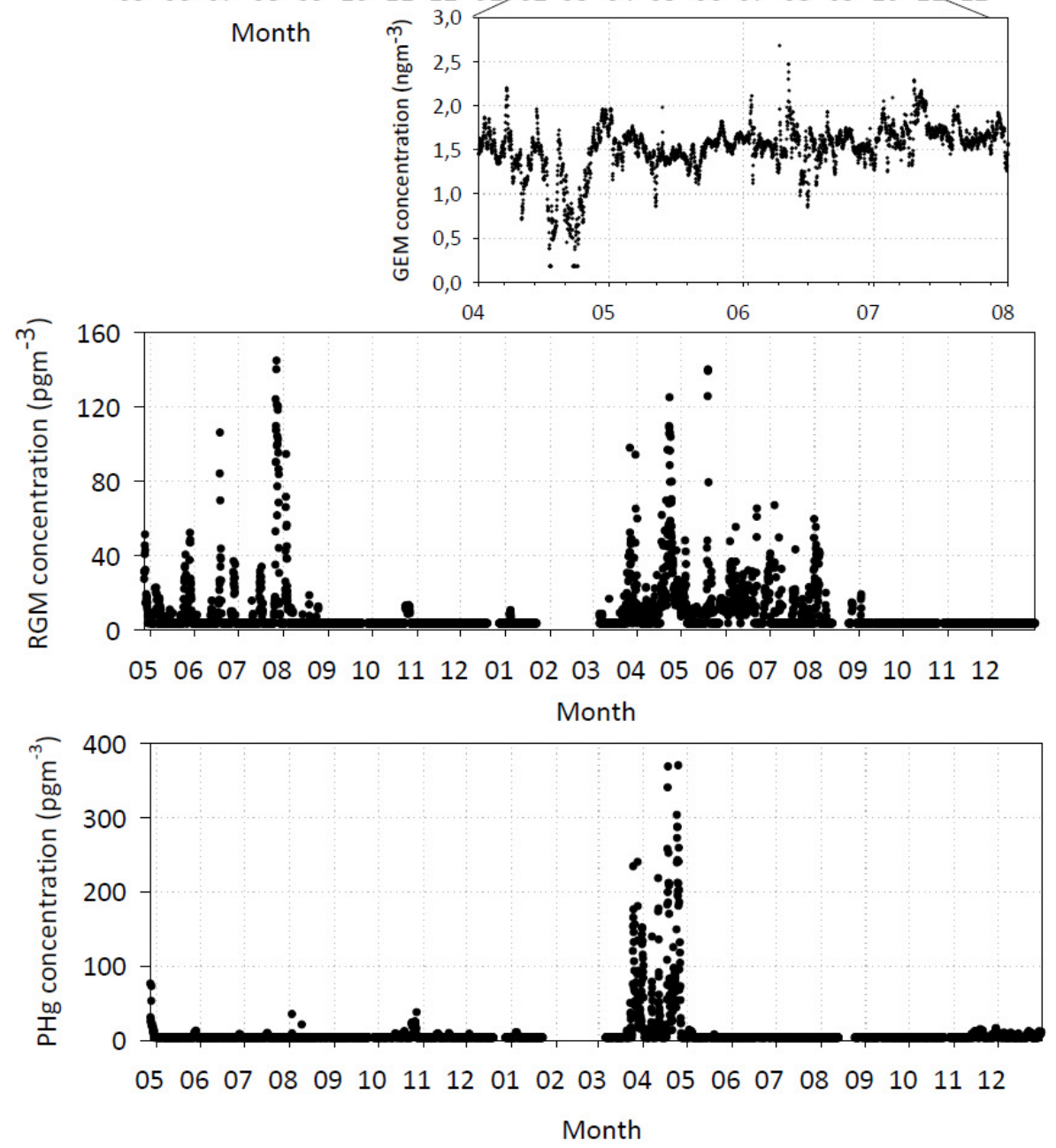

Fig. 2. Hourly average GEM concentrations, hourly average ozone concentrations and two hour average concentrations of RGM and PHg. The $\mathrm{x}$ label refers to the months from the initiation of the measurements in April 2007.

\section{Results and discussions}

\subsection{Overall atmospheric mercury fractionation}

GEM, RGM and PHg concentrations from 27 April 2007 through 31 December 2008 are presented in Fig. 2. The average GEM concentration of the complete dataset \pm one standard deviation (SD) was $1.6 \pm 0.3 \mathrm{ng} \mathrm{m}^{-3}$. The concentrations corresponded to the global background concentration of GEM in the Northern Hemisphere (1.5$1.7 \mathrm{ng} \mathrm{m}^{-3}$ ) (Ebinghaus et al., 2002; Slemr et al., 2003; Steffen et al., 2008; Temme et al., 2004) as well as to the mean surface-level GEM concentration $\left(1.6 \pm 0.2 \mathrm{ng} \mathrm{m}^{-3}\right)$ simulated at Ny-Ålesund for the observed dataset's time period by Environment Canada's Global/Regional Atmospheric Heavy Metals model (GRAHM; for details concerning the 
GRAHM see Durnford et al., 2010). The average concentrations (complete dataset) \pm one SD were $8 \pm 13 \mathrm{pg} \mathrm{m}^{-3}$ and $8 \pm 25 \mathrm{pg} \mathrm{m}^{-3}$ for RGM and PHg, respectively. The observed mean concentration of $\mathrm{PHg}$ was in good agreement with the surface-level mean concentration of $7 \pm 12 \mathrm{pg} \mathrm{m}^{-3}$ simulated by GRAHM for the observed dataset's time period at Ny-Ålesund. However, the simulated mean concentration of RGM at $23 \pm 46 \mathrm{pg} \mathrm{m}^{-3}$ was higher than observed. Since the exact emissions, chemical reaction rates, the nature of the oxidised mercury formed, the conversion between RGM and PHg, as well as the deposition rate are not known, the model is not absolutely accurate. This may in turn explain the discrepancy between the observed and simulated results. It is also difficult to compare simulated concentrations with point-source observations since a simulated value represents the average concentration for an entire $1^{\circ} \times 1^{\circ}$ grid cell while an observation represents a single location. It is also possible that the observed RGM mean concentration is somewhat too low. Aspmo et al. (2005) reported that concentrations of oxidized mercury cannot yet be quantified accurately, whereas Lyman et al. (2010) indicated that $\mathrm{KCl}$ coated denuders for collection of RGM may not be as robust as previously thought (for details see Sect. 3.2). The observed concentrations were however consistent with the RGM and PHg concentrations reported by Aspmo et al. (2005) from Ny-Ålesund using a similar fractionation system (maximum $160 \pm 57 \mathrm{pg} \mathrm{m}^{-3}$ and $63 \pm 34 \mathrm{pg} \mathrm{m}^{-3}$ for RGM and $\mathrm{PHg}$, respectively, during AMDEs). The larger standard deviations calculated for RGM and PHg, compared to GEM, reflects faster reactivity and shorter atmospheric residence time (Junge, 1972; Poissant et al., 2005).

Figures 2 and 3 clearly indicate a seasonal distribution of the GEM, RGM and PHg concentrations previously undiscovered in the Arctic. Overall, the concentration of GEM is fairly constant throughout the year apart from the abrupt concentration drops attributed to AMDEs. As proposed by Steen et al. (2009) GEM emission from surface snow, efflux from surface waters (Sommar et al., 2007) and atmospheric transport of mercury (Hirdman et al., 2009; Durnford et al., 2010) were presumed to encourage the increased GEM concentrations from April as seen in Fig. 2 and expressed by the whiskers in Fig. 3. As a net positive GEM flux was observed during polar spring in Ny-Ålesund in 2008 (Steen et al., 2009), the emission from surface snow is considered significant. Efflux from surface waters and atmospheric mercury transport prevails in summer and would account for the increased GEM concentration observed following springmelt. Increased GEM concentrations were also recorded following spring melt at Alert (Schroeder et al., 1998) and Barrow (Lindberg et al., 2002).

During polar night $\left(25\right.$ October until 18 February at $\left.79^{\circ} \mathrm{N}\right)$ the GEM concentration remains at background concentrations possibly due to the absence of atmospheric oxidants for the conversion of GEM to occur: The ozone concentration remains high (average $36 \mathrm{ppb}$ ) and the average $\mathrm{BrO}$ vertical
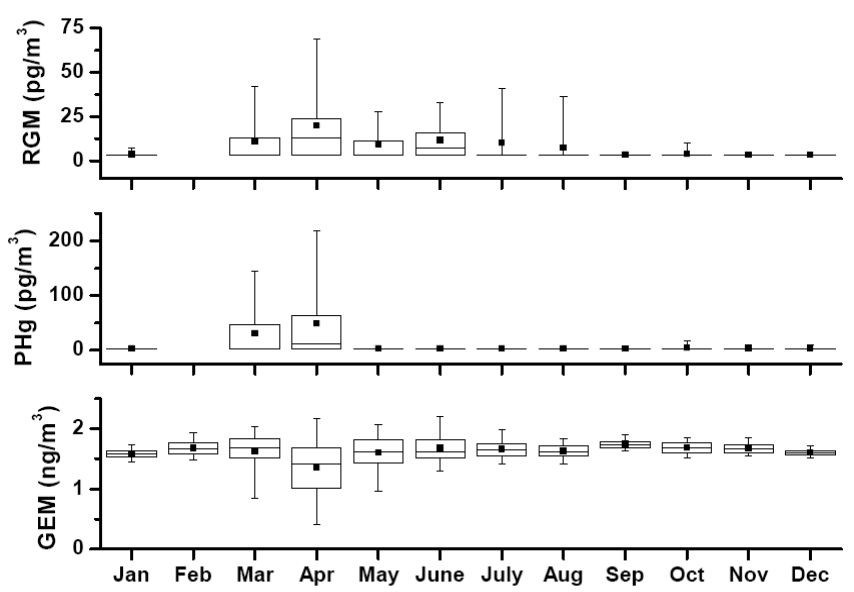

Fig. 3. Seasonal distribution of the GEM, RGM and PHg concentrations for 2007 and 2008. The box represents the monthly 25 th and 75 th percentiles of the complete dataset, the line represents the monthly median concentrations, and the black square represents the monthly average concentrations. The whiskers represent the monthly 10th and 90th percentiles of the complete dataset.

densities were below $4.0 \times 10^{-13}$ molecules $\mathrm{cm}^{-2}$ (for details see Sect. 3.2).

During polar night the RGM concentration was $<$ MDL, while the concentration increased in March $\left(11 \pm 15 \mathrm{pg} \mathrm{m}^{-3}\right)$. Note that data from February is missing. The RGM concentration from April through August $\left(13 \pm 16 \mathrm{pg} \mathrm{m}^{-3}\right)$ corresponded to the concentration during the insolation transition period in March. RGM may emit from surface snow (Skov et al., 2006), which agrees with Lindberg et al. (2002) who observed that RGM formation ceased from the onset of snow melt at Barrow. Cobbett et al. (2007) observed RGM until June at Alert. The present study is, however, the only study to date that reports increased concentrations of RGM from early March throughout August $\left(11 \pm 16 \mathrm{pg} \mathrm{m}^{-3}\right)$ in the Arctic. This indicates that RGM formation is photochemically mediated and not solely formed during AMDEs (for details see Sect. 3.4). Observations of increased RGM and GEM concentrations are supported by Soerensen et al. (2010), who suggests that factors controlling RGM are independent of the GEM source.

The increased PHg concentrations occurred almost exclusively during AMDE periods in March and April $\left(42 \pm 65 \mathrm{pg} \mathrm{m}^{-3}\right)$. RGM was considered the main precursor for the PHg existence, but long range transportation of $\mathrm{PHg}$ has to be taken into consideration. Concentrations $<\mathrm{MDL}$ during summer, in the presence of increased RGM concentrations, are possibly attributed to short-lived RGM species which are easily reduced to GEM (Schroeder and Munthe, 1998). The decreased PHg concentrations could also simply be explained by the fact that less aerosols are present in the atmosphere at this time of the year (Ström et al., 2003). 
The decreased PHg concentration could also be explained by the gas-particle partitioning work which suggests that ambient temperature (Rutter et al., 2007a) and atmospheric particle composition (Rutter et al., 2007b) may influence the RGM and PHg concentrations. Limitations associated with the Tekran affecting the RGM and PHg concentrations are discussed in Sect. 3.2.

The most credible explanations for the sudden decrease in RGM and PHg concentrations in the fall/ winter seems to be: no oxidation of GEM or local formation of RGM and PHg due complete darkness, as well as the lack of advection from sunlit source regions to the south. For the complete dataset the atmospheric distribution was $99 \%$ and $<1 \%$ for GEM and the reactive mercury fractions (RGM and PHg), respectively. In agreement with Sommar et al. (2007) PHg is the predominant reactive mercury form from March through April, while a clear shift to a predominance of RGM occurred from May through August.

\subsection{Atmospheric mercury fractionation during the spring AMDE season}

AMDEs were observed from late March until mid June. The strongest AMDEs (GEM $<$ MDL) were observed from late March until late April, and coincide with the depletion of ozone (Solberg et al., 1996) (Figs. 2 and 3). In agreement with Hirdman et al. (2009) Fig. 4 indicates that the strongest AMDEs (in 2008) originated over the Arctic Ocean. The period from March through April showed the highest monthly $\mathrm{BrO}$ vertical densities above Svalbard, indicating that reactive bromine species are contributors in the oxidation of GEM during polar spring (Lu et al., 1998; Sommar et al., 2007). Depletion of ozone supports the possibility of " $\mathrm{BrO}$ hotspots" and the following oxidation of GEM (for details see Sect. 2.3). The importance of $\mathrm{BrO}$ is in agreement with Holmes et al. (2009) who suggested that $\mathrm{Br}$ atoms were responsible for 35-60\% of the RGM, while oxidation of GEM by ozone was minor (5-20\%). Holmes et al. (2010) concluded that gas phase bromine is the main global oxidant for GEM.

The concentrations of RGM and PHg accounted for on average about $10 \%$ of the depleted GEM during the AMDEs. The remainder of the converted GEM was possibly deposited to nearby snow and ice surfaces (Aspmo et al., 2005; Lindberg et al., 2002; Steffen et al., 2002). The predominance of PHg with respect to RGM, which in turn reflects older air masses since RGM deposits at a faster rate than PHg (Zhang et al., 2009), as well as no clear meteorological regime associated with the AMDEs (discussed in Sect. 3.4) are all factors suggesting that the AMDEs are of non-local origin (Gauchard et al., 2005). There are several possible explanations for the advection of air masses from the Arctic Ocean already depleted in GEM. Ny-Ålesund is located at the ridge of the Gulf Stream delivering warm water masses to the Barents Sea, which may affect the formation mechanism for
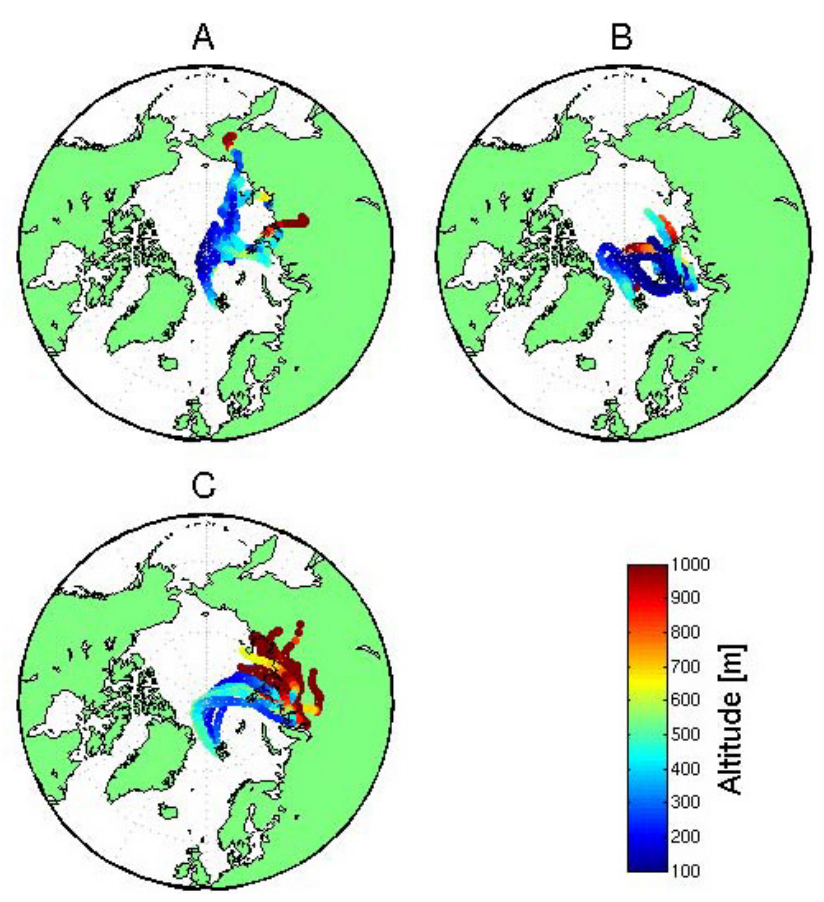

Fig. 4. 7-day back trajectories arriving in Ny-Ålesund during the strongest AMDEs in $2008\left(\mathrm{GEM}<0.54 \mathrm{ng} \mathrm{m}^{-3}\right)$. (A) $24 \mathrm{March}-$ 25 March, (B) 17 April-18 April, (C) 21 April-23 April.

RGM and PHg. Reduction in ice cover, due to the warmer water masses, would also affect the location and strength of mercury deposition due to AMDEs. It seems possible that there is an optimum combination of open water, first-year ice and snow for AMDEs to occur. Too much open water would restrict the occurrence of AMDEs (Macdonald et al., 2008).

Discussing local vs. non-local AMDEs becomes rather speculative as uncertainties exist in both the BrO plumes (see Sect. 2.3.) and the mercury fractionation methodology. As previously mentioned, Lyman et al. (2010) indicated that $\mathrm{KCl}$ coated denuders for collection of RGM may not be as robust as previously thought when exposed to $50 \mathrm{ppb}$ ozone during sample collection. Ozone concentrations above $50 \mathrm{ppb}$ were periodically observed during spring 2007 and 2008 (Fig. 2). The possibility of less efficient sample collected for RGM therefore has to be taken into consideration. Other possibilities that may influence the concentrations of RGM and $\mathrm{PHg}$ is the consequence of keeping the RPF heated at $50^{\circ} \mathrm{C}$ during sample collection (Rutter et al., 2007). Some PHg species may be semi volatile and evaporate before collection on the RPF. The possibility that RGM may partition to airborn snow and particles should also be taken into consideration. Additionally, no standardized calibration method exists to determine RGM and PHg. These are all factors indicating that the observed RGM and PHg concentrations are somewhat too low. Finally it is important to note that the GEM concentration measured by the fractionation system (Tekran 2537, 


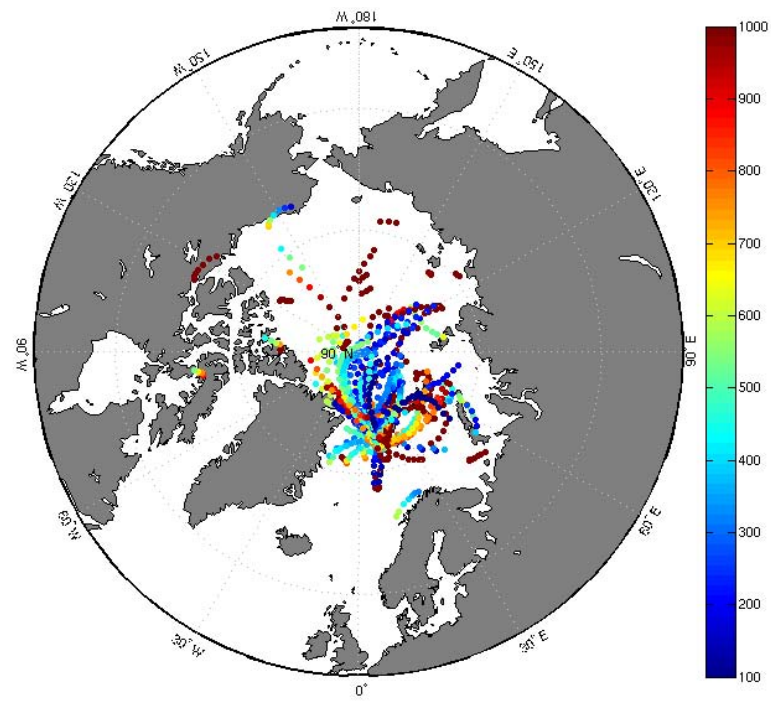

Fig. 5. 2-day back trajectories arriving in $\mathrm{Ny}$-Ålesund during periods with high RGM concentrations $(>=75$ percentile, i.e. $26 \mathrm{pg} \mathrm{m}^{-3}$ ).

1130 and 1135) at Zeppelin is periodically somewhat lower than what is measured by the Tekran 2537A. This is the main reason why a second Tekran 2537A was used to collect GEM at a five- minute resolution in this study. Advantages with the use of two Tekran 2537A units are also reported by Gustin and Jaffe (2010).

\subsection{Possible local formation and anthropogenic source areas of RGM and PHg in summer}

In summer, it is possible that the in situ ozone mediated oxidation of GEM is responsible for the observed elevated concentrations of RGM; the GRAHM, which uses ozone oxidation, is able to reproduce the elevated concentrations. The decreases in GEM concentration in summer are possibly masked by either a strong reemission of GEM from surface waters (Sommar et al., 2007; Aspmo et al., 2006) and/or the arrival of air masses with increased GEM concentrations (Durnford et al., 2010) (Fig. 2). The attendant depletion of ozone is possibly masked by the summertime arrival from the south of air masses with enhanced ozone concentrations (Fig. 2). According to the short atmospheric lifetime for RGM the 2-day back trajectories shown in Fig. 5 demonstrates that air masses elevated in RGM originated over the Arctic Ocean. Interestingly, increased concentrations of RGM and $\mathrm{PHg}$ were neither found by Aspmo et al. (2006) nor by Sommar et al. (2010) in the summer over the North Atlantic Ocean. Although a local RGM formation seems possible, the presence of anthropogenic source areas to the East are supported by the RGM and PHg emissions presented in Fig. 6. This figure presents mercury emitted during 2008 as predicted by GRAHM (Dastoor et al.,
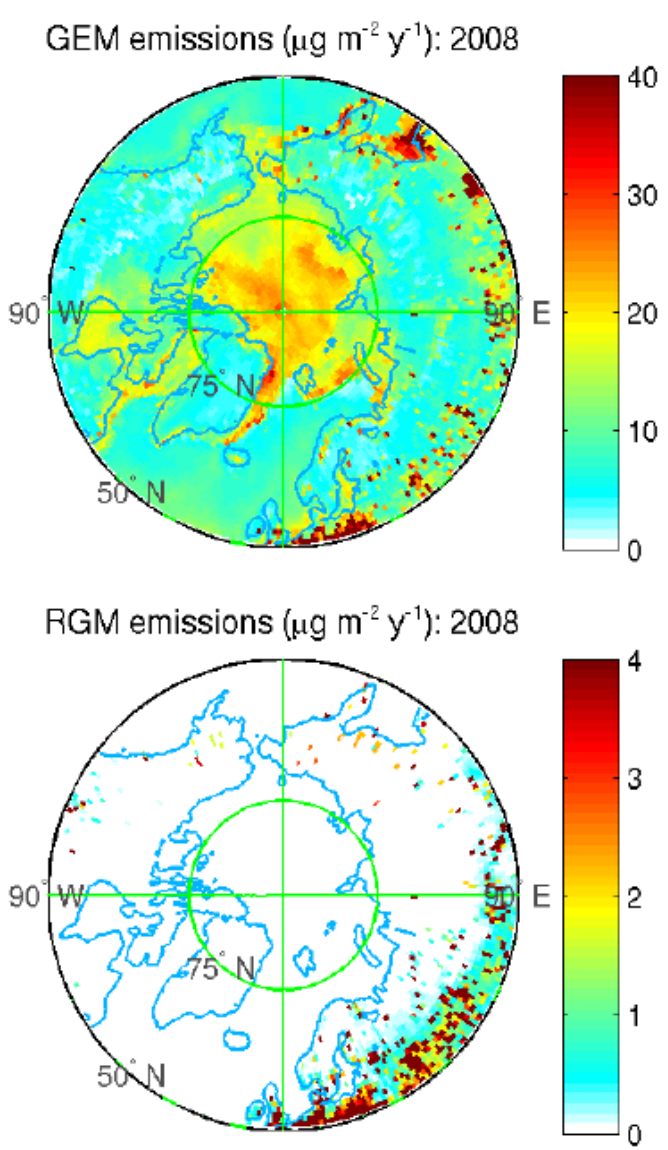

$\mathrm{PHg}$ emissions $\left(\mu \mathrm{g} \mathrm{m}^{-2} \mathrm{y}^{-1}\right): 2008$

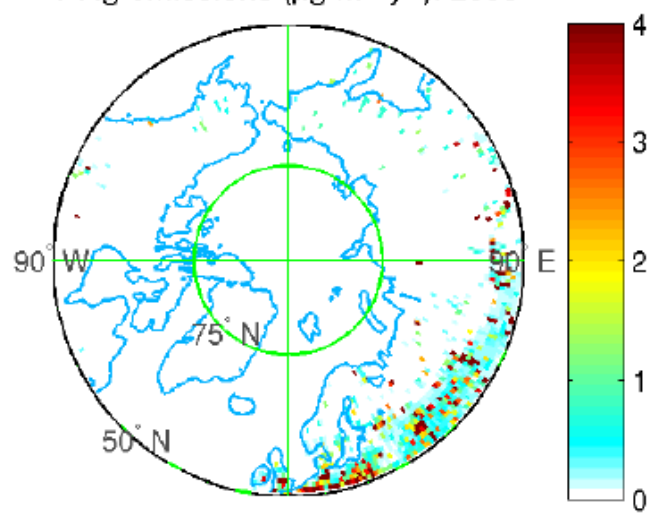

Fig. 6. Northern hemisphere high-latitude mercury emissions for 2008, as seen by Environment Canada's Global/Regional Atmospheric Heavy Metals model.

2008). Anthropogenic emission fields were produced by $\mathrm{Pa}-$ cyna et al. (2006) and are valid in 2005. GRAHM was seen to perform well in the Arctic in Dastoor et al. (2008) and Durnford et al. (2010), indicating that the emissions are accurate according to the current state of knowledge on mercury processes based on observations. Figure 6 demonstrates 
a) GEM
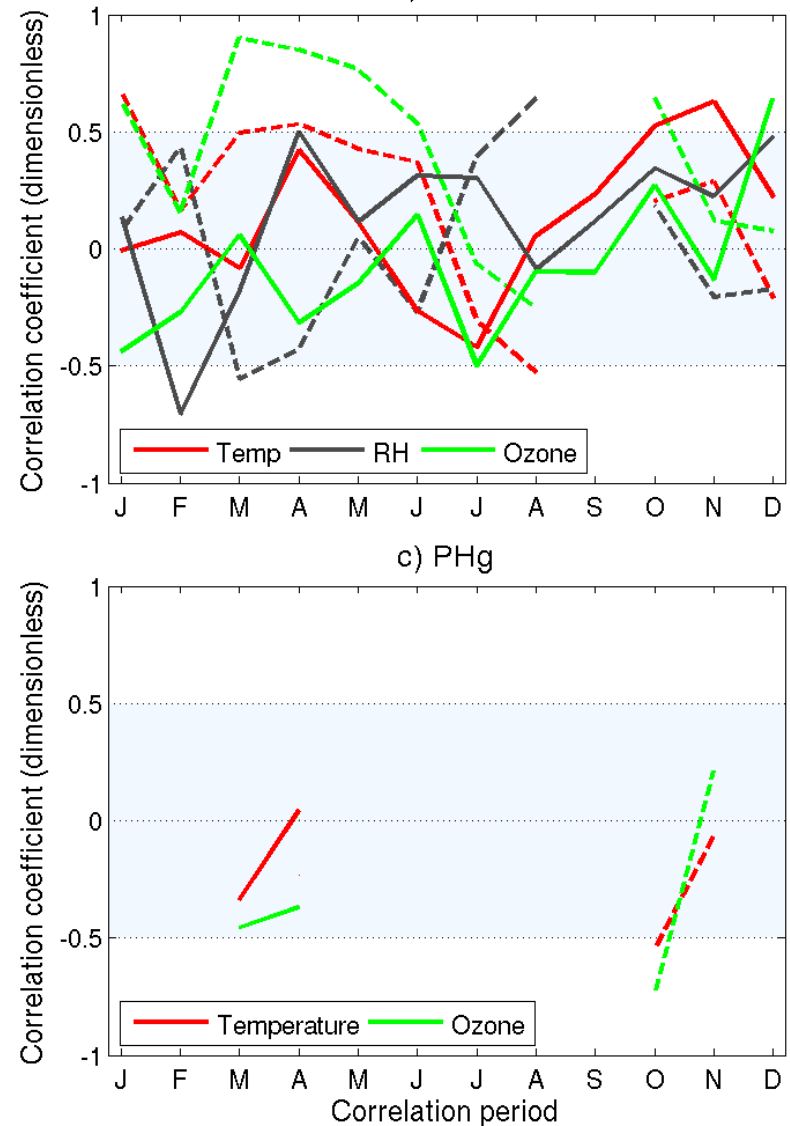

b) RGM

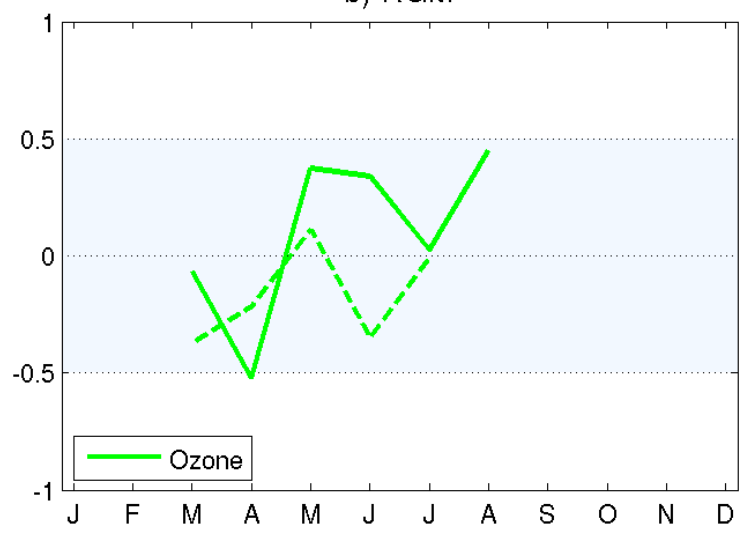

d) GEM during AMDEs

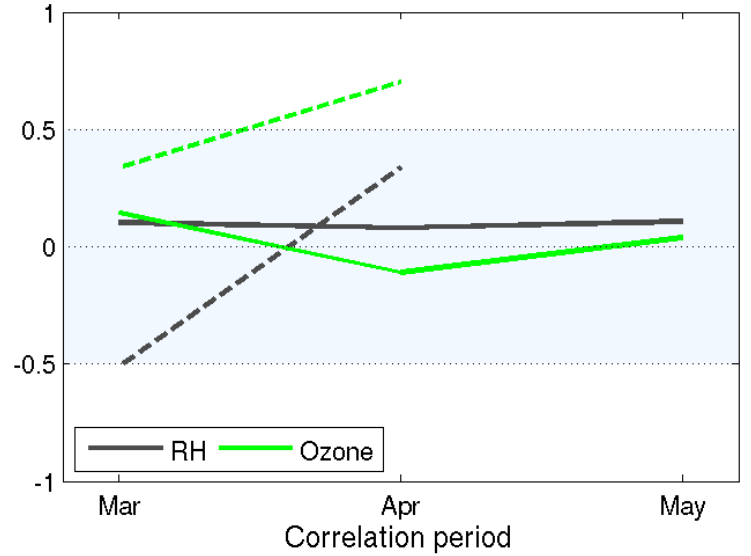

Fig. 7. Correlations of GEM, RGM and PHg concentrations with air temperature (Temp), relative humidity (RH), ozone and meridional wind. Solid lines represent correlation with high concentration ( $<75$ th percentile of the complete dataset) and dashed lines represent correlation with low concentration ( $>25$ th percentile of the complete dataset). (a) shows positive correlation of ozone and air temperature with low GEM concentrations during polar night, while relative humidity and high GEM concentrations anti correlate. The low GEM concentrations correlate with air temperature in January, March and April, and anti correlate with air temperature in August. Low GEM concentrations and ozone correlate in January, March-June and in October. Low GEM concentrations anti correlate with relative humidity in March and correlate with relative humidity in July and August. (b) shows a significant anti correlation of ozone with high RGM concentrations in April. (c) shows an anti correlation of air temperature and ozone with low PHg concentrations in October. (d) shows a correlation of ozone with strong AMDEs as spring progresses.

that northern Europe and Asia are by far the most important Northern Hemispheric high-latitude sources of RGM and PHg. Based on the short atmospheric lifetime of RGM and the 2-day back trajectories shown in Fig. 5 the contribution of RGM from sources in the northern Europe and Asia is rather doubtful. GEM emitted in the regions of Europe and Asia shown in Fig. 6 is also produced primarily by anthropogenic emissions. GEM emissions over polar waters represent the rapid reemission of mercury deposited onto the cryosphere. This process is particularly active during the spring AMDE season.

\subsection{Correlation analysis}

A correlation analysis was performed to assess the main variables associated with low and high GEM, RGM and PHg concentrations (Fig. 7), (Table 1). All calculations used the 25th and 75th percentiles of the complete dataset as thresholds for low and high concentrations, with the requirement that the monthly average correlation coefficients $(R)$ are calculated only when at least ten pairs of valid data points are available for the calculation. Only concentrations $>=$ MDL were used unless stated otherwise. In addition, a correlation analysis was performed for AMDEs. In order to include the GEM concentrations $<$ MDL observed during the strongest AMDEs, all concentrations were included in the correlation calculations, with concentrations $<\mathrm{MDL}$ set to MDL/2. All 
Table 1. Thresholds for high and low concentrations used in the correlation analysis.

\begin{tabular}{lccl}
\hline Fractions & $\begin{array}{c}\text { Low } \\
(<=)\end{array}$ & $\begin{array}{c}\text { High } \\
(>=)\end{array}$ & Concentrations \\
\hline GEM $\left(\mathrm{ng} \mathrm{m}^{-3}\right)$ & 1.6 & 1.8 & $>=0.36$ \\
RGM $\left(\mathrm{pg} \mathrm{m}^{-3}\right)$ & 10 & 26 & $>=7$ \\
PHg $\left(\mathrm{pg} \mathrm{m}^{-3}\right)$ & 9 & 45 & $>=7$ \\
AMDE $\left(\mathrm{GEM}, \mathrm{ng} \mathrm{m}^{-3}\right)$ & 0.5 & 0.9 & $>=0,<1$ \\
\hline
\end{tabular}

variables were interpolated to the fractions' times. Calculations included observations from a given month from both years in the complete dataset.

Variables with $R<-0.5$ and $R>0.5$ form the basis for this discussion. As long as either low or high mercury concentrations are sufficiently correlated $(R<-0.5$ and $R>0.5$ ) with the respective variable, the correlation coefficients for both high and low concentrations for the entire correlation period are shown in Fig. 7. Variables not strongly correlated reflect the absence of a specific meteorological regime controlling the concentrations of the given fraction (shaded area in Fig. 7).

Air temperature and ozone tend to be correlated with high GEM concentrations during polar night, while relative humidity and high GEM concentrations anti correlate. The correlation of the high GEM concentrations with ozone reflects GEM and ozone at background concentrations. The low GEM concentrations correlate with air temperature in January, March and April, and anti correlate with air temperature in August. Low GEM concentrations and ozone correlate in January, from March throughout June and in October. The low GEM concentrations tend to anti correlate with relative humidity in March and correlate with relative humidity in July and August.

Ozone was the only variable significantly correlated with RGM, where the high RGM concentrations and ozone are anti correlated in April. The importance of ozone corresponds to the oxidation of GEM by reactive bromine species, and formation of RGM during the spring AMDE season (for details see Sects. 2.3 and 3.2). It is also inviting to mention that high RGM concentrations are most pronounced in April. Although no such clear correlation was found in this study, Peterson et al. (2009) proposed that more incident light, warmer air temperatures and lower relative humidity would all promote formation of atmospheric oxidants available for oxidation of GEM and formation of RGM in summer. The absence of a significant correlation of high RGM concentrations with ozone, apart from April, suggests a seasonal variation in the relative importance of the oxidation reactions.

Ozone and air temperature anti correlate with the low PHg concentrations in October, suggesting that the highest of the low PHg concentrations are found in cold air masses low in ozone, whereas the lowest of the low $\mathrm{PHg}$ concentrations are found in warmer air masses higher in ozone. This could be explained by increased condensation of vapour phase into particulate phase at lower air temperatures (Kim et al., 2009).

Ozone was the only variable significantly correlated with the low (i.e. strongest) AMDEs, which constituted $18 \%$ of the AMDEs, indicating the presence of atmospheric oxidants for the conversion of GEM to occur (see Sects. 3.1 and 3.2). The majority of fairly low correlation coefficients calculated for AMDEs, in addition to the fairly low RGM and PHg concentrations and the predominance of $\mathrm{PHg}$ with respect to RGM, indicate that the AMDEs in this study are mainly of non local origin, with GEM being transported to Zeppelin by a wide variety of different air masses. Overall, the possibility that the observed mercury concentrations are somewhat too low may also explain that no clear meteorological regime was associated with the respective mercury forms (for details concerning caveats associated with the method used see Sect. 3).

\section{Conclusions}

The study revealed a clear seasonal distribution previously undiscovered at Polar sites: PHg was exclusively observed in March and April, while increased RGM concentration prevailed from March throughout August. Consequently, RGM was not solely formed during AMDEs suggesting that atmospheric RGM deposition also occurs during the polar summer. High RGM concentrations and ozone anti correlated in April, reflecting that reactive bromine species may be responsible for the formation of RGM to occur.

The AMDEs were possibly of non local origin with GEM being transported by a wide variety of different air masses. It was speculated whether local formation was responsible for the increased RGM concentrations in summer, as transport of anthropogenic RGM from the Northern Europe and Asia is rather doubtful.

This study gives new valuable insight into the atmospheric mercury fractionation, of outmost importance for mercury as a global pollutant. In order to further improve the knowledge this study proposes three future research directions:

- Long term atmospheric mercury fractionation measurements: previous work is generally restricted to periods of weeks to months, and this study provides clear evidence that long term measurements ( $>$ yr) will uncover new aspects concerning the temporal distribution of atmospheric mercury fractionation. Comparison of the atmospheric mercury fractionation at several polar sites is also desirable.

- Evaluation of the seasonal distribution of RGM and $\mathrm{PHg}$ : previous work is mainly conducted during spring due to the occurrence of AMDEs. However, this work revealed a clear seasonal distribution which stresses 
the importance of year- round measurements. Summer measurements at other polar measurement sites could aid in the third suggested research direction.

- Formation mechanism for RGM: RGM was observed at increased concentrations during spring and summer in the duration of this study. The formation mechanism which still remains less clear should be more carefully evaluated and it may even differ throughout the year.

Acknowledgements. Funding for this study was received from the Norwegian Research Council, NFR, (Miljø 2015 project number 181924/S30), Climate and Pollution Agency (Klif), Anders Jahres fond til vitenskapens fremme, Direktør Halvor B. Holtas legat, Svalbard Science Forum and Elkem AS. The authors would like to thank the staff at Norwegian Polar Institute and Kings Bay in Ny-Ålsund for logistic support, Alfred Wegener Institute, Koldewey station in Ny-Ålesund for meteorological data, Andrei Rijkov for providing simulated concentrations and emissions. Parameterizations improved by Andrei Rijkov and Daniel Figueras-Nieto are included in the model simulation used.

NILU is acknowledged for providing the FLEXTRA trajectories (www.nilu.no/trajectories), meteorological variables and ozone concentrations used in this study. Katarina Gårdfeldt is acknowledged for discussions and comments on this paper. The authors would like to thank the anonymous referees for detailed and helpful comments on this paper.

Edited by: F. Keutsch

\section{References}

Abbatt, J., Oldridge, N., Symington, A., Chukalovskiy, V., McWhinney, R. D., Sjostedt, S., and Cox, R. A.: Release of Gas-Phase Halogens by Photolytic Generation of $\mathrm{OH}$ in Frozen Halide-Nitrate Solutions: An Active Halogen Formation Mechanism?, J. Phys. Chem. A, 11423, 6527-6533, 2010.

Ariya, P. A., Dastoor, A. P., Amyot, M., Schroeder, W. H., Barrie, L., Anlauf, K., Raofie, F., Ryzhkov, A., Davignon, D., Lalonde, J., and Steffen, A.: The Arctic: a sink for mercury, Tellus B, 56, 397-403, 2004.

Aspmo, K., Gauchard, P.-A., Steffen, A., Temme, C., Berg, T., Bahlmann, E., Banic, C., Dommergue, A., Ebinghaus, R., Ferrari, C., Pirrone, N., Sprovieri, F., and Wibetoe, G.: Measurements of atmospheric mercury species during an international study of mercury depletion events at Ny-Alesund, Svalbard, spring 2003, How reproducible are our present methods?, Atmos. Environ., 39, 7607-7619, 2005.

Aspmo, K., Temme, C., Berg, T., Ferrari, C., Gauchard, P. A., Fain, X., and Wibetoe, G.: Mercury in the atmosphere, snow and melt water ponds in the North Atlantic Ocean during Arctic summer, Environ. Sci. Technol., 40, 4083-4089, 2006.

Berg, T., Gårdfeldt, K., Munthe, J., Sommar, J., and Wangberg, I.: Arctic mercury depletion events at two elevations as observed at the Zeppelin Station and Dirigibile Italia, Ny-Alesund, spring 2002, J. Phys.-Paris, 107, 151-154, 2003 a.

Berg, T., Sekkesaeter, S., Steinnes, E., Valdal, A.-K.,Wibetoe, G.: Springtime depletion of mercury in the European Arctic as observed at Svalbard, Sci. Total. Environ., 304, 43-51, 2003b.
Cobbett, F. D., Steffen, A., Lawson, G., and Van Heyst, B. J.: GEM fluxes and atmospheric mercury concentrations (GEM, RGM and Hgp) in the Canadian Arctic at Alert, Nunavut, Canada (February-June 2005), Atmos. Environ., 41, 6527-6543, 2007.

Dahlback, A.: Measurements of biologically effective UV doses, total ozone abundances, and cloud effects with multichannel, moderate bandwidth filter instruments, Appl. Optics, 35, 6514-6521, 1996.

Dastoor, A. P., Davignon, D., Theys, N., Van Roozendael, M., Steffen, A., and Ariya, P. A.: Modeling Dynamic Exchange of Gaseous Elemental Mercury at Polar Sunrise, Environ. Sci. Technol., 42, 5183-5188, 2008.

Durnford, D., Dastoor, A., Figueras-Nieto, D., and Ryjkov, A.: Long range transport of mercury to the Arctic and across Canada, Atmos. Chem. Phys., 10, 6063-6086, doi:10.5194/acp-10-60632010, 2010.

Ebinghaus, R., Jennings, S. G., Schroeder, W. H., Berg, T., Donaghy, T., Guentzel, J., Kenny, C., Kock, H. H., Kvietkus, K., Landing, W., Muhleck, T., Munthe, J., Prestbo, E. M., Schneeberger, D., Slemr, F., Sommar, J., Urba, A., Wallschlager, D., and Xiao, Z.: International field intercomparison measurements of atmospheric mercury species at Mace Head, Ireland, Atmos. Environ., 33, 3063-3073, 1999.

Ebinghaus, R., Kock, H. H., Coggins, A. M., Spain, T. G., Jennings, S. G., and Temme, C.: Long-term measurements of atmospheric mercury at Mace Head, Irish west coast, between 1995 and 2001, Atmos. Environ., 36, 5267-5276, 2002.

Gauchard, P. A., Aspmo, K., Temme, C., Steffen, A., Ferrari, C., Berg, T., Strom, J., Kaleschke, L., Dommergue, A., Bahlmann, E., Magand, O., Planchon, F., Ebinghaus, R., Banic, C., Nagorski, S., Baussand, P., and Boutron, C.: Study of the origin of atmospheric mercury depletion events recorded in $\mathrm{Ny}-$ Alesund, Svalbard, spring 2003, Atmos. Environ., 39, 7620$7632,2005$.

George, I. J. and Anastasio, C.: Release of gaseous bromine from the photolysis of nitrate and hydrogen peroxide in simulated seasalt solutions, Atmos. Environ., 413, 543-553, 2007.

Goodsite, M. E., Plane, J. M., and Skov, H.: A theoretical study of the oxidation of $\mathrm{Hg} 0$ to $\mathrm{HgBr} 2$ in the troposphere, Environ. Sci. Technol., 386, 1772-1776, 2004.

Gustin, M. and Jaffe, D.: Reducing the Uncertainty in Measurement and Understanding of Mercury in the Atmosphere, Environ. Sci. Technol., 44, 2222-2227, 2010.

Hirdman, D., Aspmo, K., Burkhart, J. F., Eckhardt, S., Sodemann, H., and Stohl, A.: Transport of mercury in the Arctic atmosphere: Evidence for a spring-time net sink and summer-time source, Geophys. Res. Lett., 36, L12814, doi:10.1029/2009GL038345, 2009.

Holmes, C. D., Jacob, D. J., Mason, R. P., and Jaffe, D. A.: Sources and deposition of reactive gaseous mercury in the marine atmosphere, Atmos. Environ., 43, 2278-2285, 2009.

Holmes, C. D., Jacob, D. J., Corbitt, E. S., Mao, J., Yang, X., Talbot, R., and Slemr, F.: Global atmospheric model for mercury including oxidation by bromine atoms, Atmos. Chem. Phys., 10, 12037-12057, doi:10.5194/acp-10-12037-2010, 2010.

Junge, C.: The cycle of atmospheric gases - natural and man made, Q. J. Roy. Meteor. Soc., 98, 711-729, 1972.

Kim, S.-H., Han, Y.-J., Holsen, T. M., and Yi, S.-M.: Characteristics of atmospheric speciated mercury concentrations (TGM, $\mathrm{Hg}$ (II) 
and $\mathrm{Hg}(\mathrm{p}))$ in Seoul, Korea, Atmos. Environ., 43, 3267-3274, 2009.

Kirk, J. L.: Rapid reduction and reemission of mercury deposited into snowpacks during atmospheric mercury depletion events at Churchill, Manitoba, Canada, Environ. Sci. Technol., 40, 75907596, 2006.

Landis, M. S., Stevens, R. K., Schaedlich, F., and Prestbo, E. M.: Development and Characterization of an Annular Denuder Methodology for the Measurement of Divalent Inorganic Reactive Gaseous Mercury in Ambient Air, Environ. Sci. Technol., 36, 3000-3009, 2002.

Lindberg, S. E. and Stratton, W. J.: Atmospheric mercury speciation: Concentrations and behavior of reactive gaseous mercury in ambient air, Environ. Sci. Technol., 32, 49-57, 1998.

Lindberg, S. E., Brooks, S., Lin, C. J., Scott, K. J., Landis, M. S., Stevens, R. K., Goodsite, M., and Richter, A.: Dynamic oxidation of gaseous mercury in the Arctic troposphere at polar sunrise, Environ. Sci. Technol., 36, 1245-1256, 2002.

Lindberg, S., Bullock, R., Ebinghaus, R., Engstrom, D., Feng, X. B., Fitzgerald, W., Pirrone, N., Prestbo, E., and Seigneur, C.: A synthesis of progress and uncertainties in attributing the sources of mercury in deposition, Ambio, 361, 19-32, 2007.

Lu, J. Y., Schroeder, W. H., Berg, T., Munthe, J., Schneeberger, D., and Schaedlich, F.: A Device for Sampling and Determination of Total Particulate Mercury in Ambient Air, Anal. Chem., 70, 2403-2408, 1998.

Lyman, S. N., Jaffe, D. A., and Gustin, M. S.: Release of mercury halides from $\mathrm{KCl}$ denuders in the presence of ozone, Atmos. Chem. Phys., 10, 8197-8204, doi:10.5194/acp-10-81972010, 2010.

Macdonald, R. W., Wang, F., Stern, G., and Outridge, P.: The overlooked role of the ocean in mercury cycling in the Arctic, Mar. Pollut. Bull., 56, 1963-1965, 2008.

Mayer, B. and Kylling, A.: Technical note: The libRadtran software package for radiative transfer calculations - description and examples of use, Atmos. Chem. Phys., 5, 1855-1877, doi:10.5194/acp-5-1855-2005, 2005.

Pacyna, E. G., Pacyna, J. M., Fudala, J., Strzelecka-Jastrzab, E., Hlawiczka, S., and Panasiuk, D.: Mercury emissions to the atmosphere from anthropogenic sources in Europe in 2000 and their scenarios until 2020, Sci. Total. Environ., 370, 147-156, 2006.

Peterson, C., Gustin, M., and Lyman, S.: Atmospheric mercury concentrations and speciation measured from 2004 to 2007 in Reno, Nevada, USA, Atmos. Environ., 43, 4646-4654, 2009.

Poissant, L., Pilote, M., Beauvais, C., Constant, P., and Zhang, H. H.: A year of continuous measurements of three atmospheric mercury species (GEM, RGM and Hgp) in southern Quebec, Canada, Atmos. Environ., 39, 1275-1287, 2005.

Richter, A., Wittrock, F., Eisinger, M., and Burrows, J. P.: GOME observations of tropospheric $\mathrm{BrO}$ in northern hemispheric spring and summer 1997, Geophys. Res. Lett., 25, 2683-2686, 1998.

Rutter, A. P. and Schauer, J. J.: The effect of temperature on the gas-particle partitioning of reactive mercury in the atmosphere, Atmos. Environ., 41, 8647-8659, 2007a.

Rutter, A. P. and Schauer, J. J.: The Impact of Aerosol Composition on the Particle to Gas Partitioning of Reactive Mercury, Environ. Sci. Technol., 41, 3934-3939, 2007b.

Salawitch, R. J., Canty, T., Kurosu, T., Chance, K., Liang, Q., da Silva, A., Pawson, S., Nielsen, J. E., Rodriguez, J. M., Bhartia,
P. K., Liu, X., Huey, L. G., Liao, J., Stickel, R. E., Tanner, D. J., Dibb, J. E., Simpson, W. R., Donohoue, D., Weinheimer, A., Flocke, F., Knapp, D., Montzka, D., Neuman, J. A., Nowak, J. B., Ryerson, T. B., Oltmans, S., Blake, D. R., Atlas, E. L., Kinnison, D. E., Tilmes, S., Pan, L. L., Hendrick, F., Van Roozendael, M., Kreher, K., Johnston, P. V., Gao, R. S., Johnson, B., Bui, T. P., Chen, G., Pierce, R. B., Crawford, J. H., and Jacob, D. J.: A new interpretation of total column $\mathrm{BrO}$ during Arctic spring, Geophys. Res. Lett., 37, L21805, doi:10.1029/2010GL043798, 2010.

Schroeder, W. H. and Munthe, J.: Atmospheric mercury-An overview, Atmos. Environ., 32, 809-822, 1998.

Schroeder, W. H., Anlauf, K. G., Barrie, L. A., Lu, J. Y., Steffen, A., Schneeberger, D. R., and Berg, T.: Arctic springtime depletion of mercury, Nature, 394, 331-332, 1998.

Skov, H., Christensen, J. H., Goodsite, M. E., Heidam, N. Z., Jensen, B., Wahlin, P., and Geernaert, G.: Fate of elemental mercury in the arctic during atmospheric mercury depletion episodes and the load of atmospheric mercury to the arctic, Environ. Sci. Technol., 38, 2373-2382, 2004.

Skov, H., Brooks, S. B., Goodsite, M. E., Lindberg, S. E., Meyers, T. P., Landis, M. S., Larsen, M. R. B., Jensen, B., McConville, G., and Christensen, J.: Fluxes of reactive gaseous mercury measured with a newly developed method using relaxed eddy accumulation, Atmos. Environ., 40, 5452-5463, 2006.

Slemr, F., Brunke, E. G., Ebinghaus, R., Temme, C., Munthe, J., Wangberg, I., Schroeder, W., Steffen, A., and Berg, T.: Worldwide trend of atmospheric mercury since 1977, Geophys. Res. Lett., 30, 1516, doi:10.1029/2003GL016954, 2003.

Soerensen, A. L., Skov, H., Jacob, D. J., Soerensen, B, T., Johnson, M. S.: Global Concentrations of Gaseous Elemental Mercury and Reactive Gaseous Mercury in the Marine Boundary Layer, Environ. Sci. Technol., 44, 7425-7430, 2010.

Solberg, S., Schmidbauer, N., Semb, A., Stordal, F., and Hov, O.: Boundary-layer ozone depletion as seen in the Norwegian Arctic in Spring, J. Atmos. Chem., 23, 301-332, 1996.

Sommar, J., Wängberg, I., Berg, T., Gårdfeldt, K., Munthe, J., Richter, A., Urba, A., Wittrock, F., and Schroeder, W. H.: Circumpolar transport and air-surface exchange of atmospheric mercury at Ny-Ålesund $\left(79^{\circ} \mathrm{N}\right)$, Svalbard, spring 2002, Atmos. Chem. Phys., 7, 151-166, doi:10.5194/acp-7-151-2007, 2007.

Sommar, J., Andersson, M. E., and Jacobi, H.-W.: Circumpolar measurements of speciated mercury, ozone and carbon monoxide in the boundary layer of the Arctic Ocean, Atmos. Chem. Phys., 10, 5031-5045, doi:10.5194/acp-10-5031-2010, 2010.

Sprovieri, F., Pirrone, N., Landis, M. S., and Stevens, R. K.: Atmospheric mercury behavior at different altitudes at Ny Alesund during Spring 2003, Atmos. Environ., 39, 7646-7656, 2005.

Steffen, A., Schroeder, W., Bottenheim, J., Narayan, J., and Fuentes, J. D.: Atmospheric mercury concentrations: measurements and profiles near snow and ice surfaces in the Canadian Arctic during Alert 2000, Atmos. Environ., 36, 2653-2661, 2002.

Steffen, A., Schroeder, B., Edwards, G., and Banic, C.: Mercury througout polar sunrise 2002, J. Phys.-Paris, 107, 1267-1270, 2003a.

Steffen, A., Schroeder, W. H., Edwards, G., and Banic, C.: Mercury throughout polar sunrise 2002, J. Phys. Iv, 107, 1267-1270, 2003b. 
Steffen, A., Schroeder, W. H., Poissant, L.,Macdonald, R.: Mercury in the arctic atmosphere, Indian and Northern Affairs Canada, Ottawa, 124-142, 2003c.

Steffen, A., Schroeder, W., Macdonald, R., Poissant, L., and Konoplev, A.: Mercury in the Arctic atmosphere: An analysis of eight years of measurements of GEM at Alert (Canada) and a comparison with observations at Amderma (Russia) and Kuujjuarapik (Canada), Sci. Total. Environ., 342, 185-198, 2005.

Steffen, A., Douglas, T., Amyot, M., Ariya, P., Aspmo, K., Berg, T., Bottenheim, J., Brooks, S., Cobbett, F., Dastoor, A., Dommergue, A., Ebinghaus, R., Ferrari, C., Gardfeldt, K., Goodsite, M. E., Lean, D., Poulain, A. J., Scherz, C., Skov, H., Sommar, J., and Temme, C.: A synthesis of atmospheric mercury depletion event chemistry in the atmosphere and snow, Atmos. Chem. Phys., 8, 1445-1482, doi:10.5194/acp-8-1445-2008, 2008.
Steen, A. O., Berg, T., Dastoor, A. P., Durnford, D. A., Hole, L. R., and Pfaffhuber, K. A.: Dynamic exchange of gaseous elemental mercury during polar night and day, Atmos. Environ., 43, 56045610, 2009.

Ström, J., Umegård, J., Tørseth, K., Tunved, P., Hansson, H. C., Holmén, K., Wismann, V., Herber, A., and König-Langlo, G.: One year of particle size distribution and aerosol chemical composition measurements at the Zeppelin Station, Svalbard, March 2000-March 2001, Phys. Chem. Earth, Pt A/B/C, 28, 11811190, 2003.

Temme, C., Ebinghaus, R., Einax, J. W., Steffen, A., and Schroeder, W. H.: Time series analysis of long-term data sets of atmospheric mercury concentrations, Anal. Bioanal. Chem., 380, 493-501, 2004.

Zhang, L. M., Wright, L. P., and Blanchard, P.: A review of current knowledge concerning dry deposition of atmospheric mercury, Atmos. Environ., 4337, 5853-5864, 2009. 